\title{
ONLINE INSTRUCTIONAL STRATEGIES FOR ENGLISH LANGUAGE LEARNING DURING COVID-19 PANDEMIC: A CASE FROM A CREATIVE TEACHER
}

\author{
1,2Abdul Halim; ${ }^{2}$ Sunarti \\ National Dong Hwa University, Taiwan1; \\ Universitas Muhammadiyah Kalimantan Timur, Indonesia ${ }^{2}$ \\ Corresponding email:ah918@umkt.ac.id
}

\begin{abstract}
This paper aimed at discussing online instructional strategies and learning quadrant for English language learning during COVID-19 pandemic. Therefore, the current paper reviews possible instructional strategies and learning quadrant used by a teacher in the teaching process from online platforms to ensure the educational goals are plausible to be achieved, although without having to attend classrooms regularly, especially during the COVID-19 outbreak that happens during 2019-2020. Employing qualitative design, the study involved one teacher and 34 students. The data were collected through observation and interviews with the participants. The data analysis involved data coding, data description and data assertion. The results showed that although the participants did not attend a physical classroom, the learning process with various approaches for learning and assessments were still possible to engage the students.
\end{abstract}

Keywords: Covid-19, instructional strategies, language learning, online platform

\section{INTRODUCTION}

Learning in the 21st century has evolved in many aspects. Not only has the paradigm of learning process changed, the instructions and delivery mode had also developed more advanced. Aside from traditional classroom mode, which is fully provided in the classroom where teachers and students interact face-to-face, teachers have options to have other ways of lesson delivery such as flipped classroom and full online classroom. These options provide students a sift experience from the regular classroom. They can be arranged in a range of percentages for online learning from a very little to one hundred percent online. The internet has helped teachers in lesson delivery through elearning (Moore et al., 2011). 
Many, however, still view the internet as merely some tools to be used in the classroom. It affects their instruction and limited lesson delivery. In addition, the pandemic situation that happens in 2020 is a big issue that many schools are closed to avoid unwanted case because schools are highly potential for the spread of the virus. Hence, many teachers are forced to teach through online platforms, and yet, the learning process they implemented was somehow following the traditional method.

Customarily, learning is the focus of the education process. When the students can construct their knowledge based on either through cognitive process or experience, they have already learned. In the present time, learning may occur not only in the classroom where the teacher and the students interact face-to-face for constructing knowledge, but it may also occur from a distance. Under the umbrella term of distance education, distance learning has evolved with some different terms following the current development of technology, such as distance learning, online learning, e-learning, virtual learning, web-based learning, technology-mediated learning (Conrad, 2006).

A study by Cohen \& Nachmias (2011) was conducted to trace the students' log in the learning practice through web mediated learning. It suggests that teachers can learn some aspects from the web-logs for pedagogical evaluation. This pointed out that there are some advantages that teachers can get in the process of learning through the web, namely immediate assessment, online exams, exercising, self-testing, tasks, and projects, as well as feedbacks (Cohen \& Nachmias, 2011). These advantages can be used as a reference for a theoretical framework for online learning.

The second study was aiming at exploring the impact of wiki-based international collaboration project on pre-service teachers' 1) cultural competencies, 2) the comfort using technology, including Web 2.0 tools, to interact and collaborate with unknown colleagues, and 3) perceptions of ideas for using technology, including Web 2.0 tools, in their future classrooms (Ertmer et al., 2011). In the present study, the researcher would explore the sliced part with little exploration of how the teachers use their competence in the teaching approach, specifically their instructional strategies for their online delivery of the lessons.

The third study was about the flipped classroom that took advantage of computer-assisted language learning (CALL). The study explored how the flipped classroom would benefit students' language acquisition since the flipped classroom was designed for the student to be the center of learning (Bauer-Ramazani et al., 2016). In the present study, the researcher tried to explore how the teacher can maximize the principles from the online stage of the flipped classroom, not only can the teacher use the initial stage as the concept delivery, but also the whole learning process as the government 
reinforces it through the ministry of education as the way of learning during the pandemic situation.

The fourth study investigated how blended learning by using an elearning system would influence the students learning and the achievement of learning objectives. The results indicated that the students and the teacher would positively perceive the model of e-learning systems with innovative characteristics such as ease of use, logical and systematics, interactive, and appealing. It would lead to learning achievement (Chaeruman et al., 2018). However, the classes involved in that study were characterized by blended learning that relies on both traditional face-to-face and virtual classes. In the present study, the setting was entirely virtual class.

The present study, the researcher found a teacher in a public school in the capital province in central Indonesia that is quite different and is worth for research exploration. Therefore, the study aimed to explore what and how a teacher in a school handled the classroom amid COVID 19 outbreak. Then, it would have the contribution to fill the gap of the previous studies(BauerRamazani et al., 2016; Chaeruman et al., 2018; Cohen \& Nachmias, 2011; Ertmer et al., 2011) that it would use the framework of online learning for data analysis of the class that happened during the pandemic where all teachers and students were forced to learn at home with teacher's facilitation through online platforms. It aimed to explore the teacher's pedagogical approach in lesson delivery in such a setting that it would be different from conventional blended learning or flipped classroom. The nature of the current study setting was also unique than of the fully online courses through MOOC.

\section{METHODS}

\section{Participants}

By employing a qualitative research design, the study involved one female English teacher and 34 students whom 20 were females, and 14 were males. All participants, the teacher, and the students were informed that they were involved in the study. They were asked to read and to sign a research consent.

The participants in this study were intentionally chosen by the researcher that they fulfil the criteria of uniqueness the initiated the study. Where many of the classrooms during the process of online learning were found to be demanding and exhausting for the students, this teacher did direct her class in an interesting way that the researcher considered her "creativity" in conducting the classes worth studying. The creative ways she used to utilize some conventional online media can be investigated through some theoretical perspective.

\section{Setting}


The study took place in central Indonesia. The researcher had access to a public high school in the capital of the province. The school was a typical school with the number of students around $600-800$ students. The researcher and the teacher agreed to get a class of grade 10th to be involved in the study. The class was chosen based on the initial interview with the teacher. Before the research took place, the researcher interviewed the teacher about the teaching process she was facing, the difficulties, and the teaching plans that she would do. The result showed that it had potential and worth for research.

The research was conducted during the pandemic situation. The COVID-19 disease started in late 2019 and continued to spread until in the middle of 2020 in the world. In Indonesia, right after the president's instruction in the middle of March 2020, when some of the first the cases were confirmed in the country, the classes at school were called off for virus spread prevention, and since then, all education levels in Indonesia were instructed to deliver their learning online. 'Study from home' was imposed because the government did not want to risk the students at school. In such a setting, the learning process happened at home with the teacher's facilitation through online platforms. Therefore, although all the conventional learning process at school stopped, it had to continue at home to ensure the curriculum's content materials were still delivered.

\section{Procedures and Data Analysis}

The procedure started with the problem analysis found by the teacher and how the teacher solved the problems. The researcher was involved in the learning process as an external observer that the researcher did not have an active role in participating in the activity but present in the digital platforms. The reason for being an inactive external observer during the learning process was that the researcher expected his presence to be less obvious so that the threat for the Hawthorne effect can be minimized. The teacher used various digital platforms such as YouTube, Google Classroom, Zoom, WhatsApp, and Google Docs collaboration.

The observation took place for two months. The teacher had the WhatsApp group to handle the instruction to the students so she could tell the students what to do during the learning process and used other platforms to deliver the lesson or to assess the learning outcome.

The researcher used field notes to record all the activities. The copy of students' work on all platforms includes the documents from google classrooms, google forms, YouTube links, WhatsApp chats, and zoom records. These data were used to investigate the pedagogical approach used by the teacher to teach the students. In addition, the data were also used to determine the learning quadrant experienced by the students that has been designed by the teacher. The data from the semi-structured interview session 
was used to confirm the decision making from the teacher and the students' perception of what they had done during learning activities.

\section{FINDINGS}

The government of Indonesia announced its policy to stay at home as the COVID-19 was getting more severe in the country in the middle of March 2020. People were expected to work from home. It also affected the students at school where they should learn from home. The teacher was informed. She decided to look at the curriculum. A range of lessons for the semester has not been covered in the learning with the students. This would be the basis of her teaching in the future during work from home.

Initially, the teacher set up a WhatsApp group for the students. The group functioned as the announcement board, or for feedback if the students had difficulties. It is beneficial since reciprocal communication could occur on the platform. Also, the application supported sending documents such as word, excel, and PowerPoint, photos, videos, internet links, etc. The researcher at the beginning joining the group hypothesized that the teacher would heavily rely on the WhatsApp group, and the learning process would fall flat, and the students would only learn from home like normal where they only get some homework and submit their work once finished. However, it turned out that this WhatsApp group was not the primary application used by the teacher, as she often instructed the students to learn from different resources. The following is the example of the learning process from observation note for chapter 8, 'My Idol':

The teacher told the students through WhatsApp group for their learning for the week that they should have a Gmail account. She gave the time for the students to create an account because it was necessary for their learning. She created a google doc with an open sharing account. Therefore, every student would be able to access the file synchronously, real-time. All students were required to log in at the same time.

On Google Docs, the teacher posted two pictures of two famous people from a different field. The teacher instructed the students to guess who they were. Here, the students commented directly on the document.

The lesson continued for vocabulary building. The teacher asked the students to work in pairs through the WhatsApp voice call. They should work collaboratively to finish the task. They should work on their textbook and have a similar answer as a pair. Once the time given for them finish, the students got back on google docs, and all pairs simultaneously posted the photographed of their answer. The teacher gave respond and feedback. 
For pronunciation practice, the students were asked to type each word from the textbook and listen to the voice. They were requested to record their voice mentioning all the words and then added two sentences for their examples.

The teacher gave the students 20 minutes to read a text about an Indonesian singer and answer the questions. He told the students that they would have a zoom meeting that the students had previously installed on their phone to discuss their work results.

They spent another 20 minutes discussing the correct answer for the student's work. The class continued with some highlighted grammar explanation from the text.

The students continued with google form designed by the teacher to assess the students learning on that day.

At home, they were asked to make a presentation of a famous person profile on Ms. PowerPoints and have two-on-two presentation via zoom application with screen sharing with their peers and required to record their presentation. The videos were uploaded to YouTube, and the link to the video was submitted to the teacher.

The example above was one of the classes held by the teacher. In one meeting, she managed to have the class that was as interactive as possible. Unlike the flipped classroom, where the students have pre-activity to learn the concepts and have more student-centred activities in the classroom, the instruction approach applied by the teacher used other platforms such as Zoom, google docs, and YouTube as the media for collaborative learning.

\section{DISCUSSION}

\section{Teacher's Instructional Strategies}

The researcher found that the teacher used a variety of teaching strategies so that the teaching was not (borrowing the teacher's term) 'dull.' Based on the observation, this technology-mediated learning also facilitated the students to construct their knowledge through facilitation. The teacher often initiated the learning through multiple and segmented tasks that the students could accomplish. It seemed that the scaffolding process was the basis of the learning implemented by the teacher. The principles used by the teacher in this study have confirmed the scaffolding techniques where the prepared lesson helped the students to access their prior knowledge and use them for further steps of learning (Mehisto et al., 2008).

In the learning process in the study, it was also still possible to have the collaborative learning strategies that previously may have been thought impossible for some teachers to implement. Some might think that the learning process through online platforms was limited because interaction on 
the web was usually between teacher-students. However, the research participants in this study proved that the learning process could be done collaboratively through ma variety of online platforms. They could also learn both synchronously and asynchronously (Chaeruman et al., 2018).

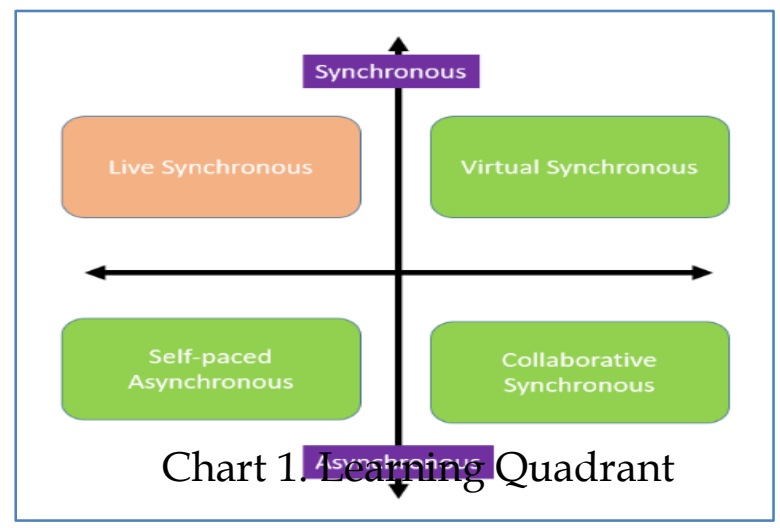

The chart above illustrates the learning quadrant. The students and teacher whose class was conducted held during the pandemic situation where students and teachers could not go to school were still able to get the most of the learning process. The observation in this study showed that the teacher could lead the learning process through three quadrants. In virtual synchronous, where the teaching and learning occurs at the same time (Raharjo, 2020), teachers and students could have online meetings through some applications such as Zoom, Google Meets, or even WhatsApp for a smaller group. They could communicate with each other and applied some instructional approach that foster students' skills and simultaneously works on the students' interest so that the learning process could be smooth.

Collaborative asynchronous may also occur in the process of online learning. In the previous example, the teacher showed that homework tasks have the potential for collaborative learning that occurs anywhere. It means that the students have the independence to learn with their peers. Hence, autonomous learning is fostered together with their peers. Students could decide together with their peers for the learning process mediated by available online application.

Furthermore, Self-paced asynchronous could also occur where students independently have access to learning anytime and anywhere. In this study, the teacher facilitated his students to learn online through uploaded materials on google classrooms, YouTube for video materials, and ready-touse google form assessment with immediate feedback. It means that the students could do their learning freely. 
Not only the mode of lesson delivery did the teacher make the most for the students' learning, but she also considered how the students learn. It was crucial because the learning process would have a greater effect to the students when they feel being cared for (Gay, 2010). The teacher also has paid attention to the students' learning style as it is essential to students learning development (Mehisto et al., 2008). By paying attention to this factor, the students were observed to be more motivated. Further, when the students were more motivated, the results were desirable (Kyndt et al., 2011).

\section{Assessing Students}

In this study, the researcher also found the process of assessment that was conducted by the teacher. The evaluation process took place in the progress of learning, the formative test, and at the end of the learning process called the summative test (Brown, 2003). The teacher ran the formative assessment during the learning process by giving them online exercise and directly scoring on the students' progress on the web. At the end of the course, an online test was given to the students for the final exam. The test consists of multiple-choice questions, short answer, and short essay questions to test their reading, listening and writing. Some types of these tests would offer both teachers and students convenience as they could have immediate feedback, right after finishing the test (Cohen \& Nachmias, 2011). Meanwhile, speaking skill was assessed through a video call.

The alternative assessment was another assessment done by the teacher as a supplementary to the tests. Students were asked to collect the product of their works during the course to get an additional score. The types of work they should collect include videos, PPT slides, collaborative writing on google docs. This type of assessment was suitable too for the students because not only did they work on the task, the process of collecting information and prior knowledge used for the work was stimulated. The activity could help the students pass the zone proximal development (Mehisto et al., 2008). Some platforms, such as Google Docs, allowed the students to work collaboratively in real-time (Halim et al., 2019). The students also showed that they could work together with a positive attitude.

\section{CONCLUSION AND SUGGESTION}

The development of technology, especially the internet of things, has brought a significant shift in education. Educators have the opportunity to enhance their teaching practices and the students' experience in learning. Traditionally teacher and students learn in a face-to-face setting at the same place at the same time. However, the quadrant of learning offers more. They may learn in more diverse settings such as live synchronous, collaborative asynchronous, and self-paced asynchronous. In addition, online mediated learning also 
offers the ease of assessment process. Whether it is the formative and summative test or the alternative assessment, the process of assessing the students can be more varied and the scoring can be done more easily. As discussed by the researcher, the findings of the study revealed the learning through online platforms would not hinder the learning process as long as the pedagogical approach was being considered by the teacher considering the characteristics of students' learning style and collaborative learning.

Such learning settings could be the solution for teachers and students to learn during the pandemic that happened in the world during 2020. It was also important to note that the teacher could still make the students get the most of the lesson by paying attention to teaching and learning principles. The teacher should pay attention to the mode of delivery that not only does it promote independence in learning, but the students' learning style, students' cultures, and student-centeredness should also be considered.

The study somehow also has some limitations: the participants' setting was that they were from the province's capital. Most of the activities could happen because both parties, the teacher and students, had the facilities and were technology literate. The study's findings might be different if it were carried out in a place where not all of the students have access to such technology and have limited access to the internet.

The future researcher could make the findings of the current study for conducting more profound research in the future to see if teachers have positive attitudes towards the learning process, how it would influence their teaching beliefs, and whether it would influence the students' achievement. Some study on students' psychological development and congruence with the learning setting through different platforms could also be explored.

\section{REFERENCES}

Bauer-Ramazani, C., Graney, J. M., Marshall, H. W., \& Sabieh, C. (2016). Flipped Learning in TESOL: Definitions, Approaches, and Implementation. TESOL Journal, 7(2), 429-437. https://doi.org/10.1002/tesj.250

Brown, H. D. (2003). Language Assessment: Principles and Classroom Practices. Pearson ESL.

Chaeruman, U. A., Wibawa, B., \& Syahrial, Z. (2018). Creating a Blended Learning Model for Online Learning System in Indonesia. International Journal of Engineering $\mathcal{E}$ Technology, 7(3.36), 156-159. https://doi.org/10.14419/ijet.v7i3.36.29098

Cohen, A., \& Nachmias, R. (2011). What can instructors and policy makers learn about Web-supported learning through Web-usage mining. Internet and Higher Education, 14(2), 67-76. https://doi.org/10.1016/j.iheduc.2010.07.008 
Conrad, D. (2006). E-Learning and social change: An apparent contradiction. In Perspectives on higher education in the digital age (pp. 21-33). Nova Science Publishers.

Ertmer, P. A., Newby, T. J., Yu, J. H., Liu, W., Tomory, A., Lee, Y. M., Sendurur, E., \& Sendurur, P. (2011). Facilitating students' global perspectives: Collaborating with international partners using Web 2.0 technologies. Internet and Higher Education, 14(4), 251-261. https://doi.org/10.1016/j.iheduc.2011.05.005

Gay, G. (2010). Culturally Responsive Teaching: Theory, Research, and Practice (Second eds). Teachers College Press.

Halim, A., Khatimah, K., Rachman, D., Lubis, A. A., Sunarti, S., Puspita, R. H., \& Rahmawati, Y. (2019). EXPLORING EFL STUDENTS' EXPERIECENS ON ONLINE-BASED WRITING PORTFOLIO. Acitya Journal of Teaching and Education, 1(1), 1-9. http://journals.umkt.ac.id/index.php/acitya/article/view/200

Kyndt, E., Dochy, F., Struyven, K., \& Cascallar, E. (2011). The direct and indirect effect of motivation for learning on students' approaches to learning through the perceptions of workload and task complexity. Higher Education Research and Development, 30(2), 135-150. https:// doi.org/10.1080/07294360.2010.501329

Mehisto, P., Marsh, D., \& Frigols, M. J. (2008). Opening windows for personal achievement. In Uncovering CLIL: Content and language integrated learning in bilingual and multilingual education (pp. 138-171). McMilan.

Moore, J. L., Dickson-Deane, C., \& Galyen, K. (2011). E-Learning, online learning, and distance learning environments: Are they the same? Internet and Higher Education, 14(2), 129-135. https://doi.org/10.1016/j.iheduc.2010.10.001

Raharjo, D. H. (2020). Feasibility Test of English Instructional. Journal of Applied Linguistics and Literature, 5(2), 109-122. https://doi.org/http://dx.doi.org/10.33369/joall.v5i2.10753 